\title{
The Association of Sleep-Related Breathing Disorders Among Pediatric Patients with Allergic Rhinitis: A Cross-Sectional Study in a University Hospital
}

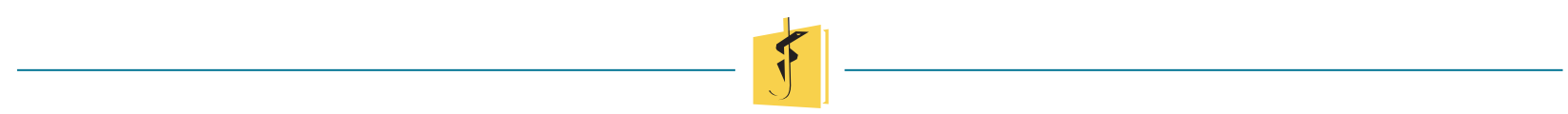

Jamie Olivia C. Go, MD, Olivia C. Go, MD, and Clara R. Rivera, MD

\begin{abstract}
Introduction: Allergic rhinitis is a common condition in children linked to sleep-related breathing disorders (SRBD). Because of nasal congestion, it can cause obstructive sleep apnea, sleep fragmentation, and excessive fatigue. Studies regarding its association with SRBD is limited.

Objectives: To determine the association of allergic rhinitis with sleep-related breathing disorders.

Methodology: A cross-sectional analytical study involving pediatric patients diagnosed with allergic rhinitis was conducted. Allergic rhinitis severity was evaluated with the ARIA classification. SRBD was identified using the validated Filipino version of the pediatric sleep questionnaire. Potential association between allergic rhinitis and SRBD were assessed using the student's t-test, Fisher's exact test and odds ratio.
\end{abstract}

Results: A total of 66 children with mean age 8.2 years were included in the study. The mean age, weight, height, and $\mathrm{BMI}$ were comparable among participants who were positive or negative for obstructive sleep apnea (OSA). Among the perceived problems related to sleeping disorders, snoring

Jamie Olivia C. Go, MD

jamieolivia627@gmail.com

Department of Pediatrics, Section of Pulmonology,

University of Santo Tomas Hospital, Manila, Philippines loudly, heavy breathing, dry mouth of awakening, not listening, and difficulty organizing showed different responses $(p<0.05)$ among the subgroups of allergic rhinitis. The odds ratio of snoring loudly, not listening, difficulty organizing, heavy breathing, and unfreshened in the morning were more likely among patients with mild persistent allergic rhinitis compared to patients with mild intermittent allergic rhinitis.

Conclusion: There was sufficient evidence to prove the association of SRBD with severity of allergic rhinitis using the validated Filipino version of the Pediatric Sleep Questionnaire. OSA shows a greater likelihood among patients with mild persistent allergic rhinitis compared to those with mild intermittent allergic rhinitis.

Key words: allergic rhinitis, sleep-related breathing disorders, obstructive sleep apnea, pediatric sleep questionnaire

\section{INTRODUCTION}

Sleep-related breathing disorders (SRBD) encompass conditions such as obstructive sleep apnea syndrome, central sleep apnea, upper airway resistance syndrome, and obesity hypoventilation syndrome. Common symptoms include loud snoring, paradoxical movement of the chest and abdomen, apnea during 
sleep, difficulty breathing with snorting, cyanosis, sweating, restless sleep, frequent awakenings, night terrors, daytime hypersomnolence, fatigue, reduced ability to function, and headache.[1]

The prevalence of SRBD among the pediatric population has constantly increased in the last few decades. This condition has significantly affected the quality of life of children and has been associated with neurobehavioral and cognitive problems, metabolic ailments (insulin resistance and hyperlipidemia), cardiovascular disorders (cor pulmonale, systemic and pulmonary hypertension), growth and developmental abnormalities, and death. Unfortunately, due to ignorance and/or lack of awareness of its clinical occurrence in children, SRBD remains underdiagnosed.[1] Thus, it is recommended that physicians be wary of its existence and exert vigilance in detecting SRBD in children to obviate the harmful consequences of the disease.

Overnight polysomnography remains the gold standard for the diagnosis of SRBD. However, it cannot predict clinically significant morbidity or disease burden in children.[2,3] In addition, not all institutions are equipped with sleep laboratories and many hospitals do not have in-house pediatric sleep specialists. Moreover, the time, effort, and expense of the procedure can be restrictive and burdensome for both the child and the family.[4] As such, alternatives in the form of questionnaires for the evaluation of SRBD have been formulated and validated.

The Pediatric Sleep Questionnaire (PSQ) Sleep Related Breathing Disorder Subscale is a 22-item questionnaire used as a screening tool. It has a sensitivity of $81 \%$ and a specificity of $87 \%$ in predicting SRBD, with good internal consistence and test-retest reliability. [4] It has been validated in several studies and has been shown to better predict neurobehavioral outcomes compared to overnight polysomnography. $[2,3,5]$ It has also been translated into different languages to address the need for culturally appropriate and linguistically accessible questionnaires. Recently, a Filipino version of the pediatric sleep questionnaire was formulated and validated. [6]

Allergic rhinitis is a common chronic respiratory illness in children characterized by nasal congestion, sneezing, and nasal itchiness.[7] Inflammation of the nasal mucosa is the main pathophysiologic mechanism of allergic rhinitis that leads to clinical symptoms of nasal congestion, rhinorrhea, sneezing, and nasal itching, often worse at night.
Consequently, patients develop manifestations similarly seen in patients with SRBD such as mouth breathing, arousing irritability, sleep fragmentation, headaches, and fatigue.[8]

To date, there are no local studies correlating SRBD with allergic rhinitis. It is therefore the objective of this study to determine the association of allergic rhinitis with SRBD in children. Using the validated Filipino version of the pediatric sleep questionnaire, early recognition of sleep-related breathing disorders in patients with allergic rhinitis is possible, enabling early referral to a specialist for appropriate management and consequently, preventing recognizable complications.

\section{METHODOLOGY}

The research was a cross-sectional analytical study conducted in the University of Santo Tomas Hospital ambulatory care services or private clinics.

Children aged 1-17 years and 364 days old diagnosed with allergic rhinitis were included in the study. Participants with craniofacial or neuromuscular anomalies, chronic hypertrophic tonsils, those who underwent tonsillectomy, and participants on corticosteroid, leukotriene receptor antagonist or antihistamine therapy were excluded.

Allergic Rhinitis and its Impact on Asthma (ARIA) guidelines [9] was used for allergic rhinitis diagnosis and classification. Participants were classified as either mild intermittent, mild persistent, or moderate persistent according to the chronicity of the symptoms, and if these symptoms have significant effect on daily activities.

The study used the validated Filipino version of the SRBD subscale within the PSQ (Appendix A). It contains 22 items documenting the presence or absence of symptoms such as snoring, observed apneas, difficulty in breathing during sleep, daytime sleepiness, and inattentive or hyperactive behavior. The positive responses will be scored as 1 and negative responses as 0 . The overall score will be divided by 22 to provide a final value. A cut-off value of eight positive responses is thought to be most effective in identifying OSA. Permission was acquired from the author through electronic mail granted on August 15, 2018. A license agreement for digital downloading was likewise obtained.

The study commenced with the approval by the Research Ethics Committee. Informed written 
consent, verbal assent and/or simplified assent were obtained. Baseline demographic and clinical data were recorded. The validated Filipino version of the SRBD subscale within the PSQ was given to the parent/guardian of the participant to answer and was collected afterwards.

\section{Statistical Analysis}

Mean and standard deviation were used to summarize the age, weight, height, BMl, and score in the pediatric questionnaire. Counts and percentages were used in gender, classification of BMI, severity of allergic rhinitis, and sleeping disorders. The Student's t-test was used in comparing age, weight, height, and BMI of patients with and without OSA. Fisher's exact test was used in comparing the sex and BMI classification of those with and without OSA. Fisher's exact test, including odds ratio, was used in association of sleeping disorders and severity of allergic rhinitis.

All statistical tests were performed in $R$ ver 3.6.1, at $5 \%$ level of significance.

\section{RESULTS}

A total of 66 patients were included in the study, with mean age of 8.2 years (range, 1 to 17). There were $33(50 \%)$ males and $33(50 \%)$ females with mean weight of $30.7 \mathrm{Kg}$ (range, 9.0 to 83.40 ), mean height of 126.2 (range, 70 to 173) and mean BMI of 17.6 (range, 10.5 to 29.4$)$. Five $(7.6 \%)$ patients had $\mathrm{BMI}$ above the normal range and six $(9.1 \%)$ below the normal range (Table 1).

Based on their pediatric sleep questionnaire responses, they had a mean positive response (score) of 5.4 (range, 1 to 11 ). Eighteen (27.3\%) had at least eight positive responses indicating positive OSA, while 48 (72.7\%) had less than eight positive responses indicating negative OSA.

The mean age $(p=0.125)$, weight $(p=0.059)$, height $(p=0.110)$, and BMI $(p=0.053)$ did not significantly differ among patients who were positive or negative for OSA. Likewise, there were no correlations between sex $(p=0.783)$ and $B M I$ classification ( $p=0.103$ ) with OSA.

Participants were classified as mild intermittent, mild persistent, or moderate persistent according to the ARIA classification. There were sufficient evidences to prove the association of OSA with severity of allergic rhinitis $(p<0.001)$. Data showed that patients with mild persistent allergic rhinitis had an odds ratio of 9.1 [95\% Cl: 2.3 to 44.9] or $90.9 \%$ chance of having OSA ( $p<0.001$ ). On the contrary, patients with mild intermittent allergic rhinitis had an odds ratio of 0.02 [95\% Cl: 0.00 to 0.19$]$ or were $98 \%$ less likely to have OSA $(p<0.001)$. However, this correlation was not observed among patients with moderate persistent allergic rhinitis $(p=0.441)$ (Table 2).

Table 1. Demographic profile of participants with allergic rhinitis with or without sleep-related breathing disorders.

\begin{tabular}{|c|c|c|c|c|c|}
\hline \multirow{2}{*}{\multicolumn{2}{|c|}{ Demographics }} & \multirow[t]{2}{*}{ ALL } & \multicolumn{2}{|c|}{ Obstructive sleep apnea } & \multirow[t]{2}{*}{ p-value } \\
\hline & & & $\begin{array}{l}\text { Positive } \\
\text { (score } \geq 8)\end{array}$ & $\begin{array}{l}\text { Negative } \\
\text { (score <8) }\end{array}$ & \\
\hline \multicolumn{2}{|c|}{ Number of Patients } & 66 & $18(27.3 \%)$ & $48(72.7 \%)$ & \\
\hline \multicolumn{2}{|c|}{ Age } & $8.2 \pm 5.2$ & $9.8 \pm 4.7$ & $7.6 \pm 5.3$ & 0.125 \\
\hline \multirow[t]{2}{*}{ Sex: } & Male & $33(50.0 \%)$ & $8(44.4 \%)$ & $25(52.1 \%)$ & 0.783 \\
\hline & Female & $33(50.0 \%)$ & $10(55.6 \%)$ & $23(47.9 \%)$ & \\
\hline \multicolumn{2}{|c|}{ Weight (in kg) } & $30.7 \pm 18.6$ & $37.8 \pm 20.8$ & $28.1 \pm 17.3$ & 0.059 \\
\hline \multicolumn{2}{|c|}{ Height (in cm) } & $126.2 \pm 28.4$ & $135.3 \pm 24.1$ & $122.7 \pm 29.4$ & 0.110 \\
\hline \multicolumn{2}{|c|}{ BMI (in kg/m²) } & $17.6 \pm 4.1$ & $19.1 \pm 5.8$ & $17.0 \pm 3.0$ & 0.053 \\
\hline \multicolumn{6}{|c|}{ BMI-for-age Classification: } \\
\hline \multicolumn{2}{|c|}{ Obese } & $1(1.5 \%)$ & $1(5.6 \%)$ & $0(0 \%)$ & 0.103 \\
\hline \multicolumn{2}{|c|}{ Overweight } & $4(6.1 \%)$ & $4(22.2 \%)$ & $0(0 \%)$ & \\
\hline \multicolumn{2}{|c|}{ Normal } & $55(83.3 \%)$ & $12(66.7 \%)$ & $43(89.6 \%)$ & \\
\hline \multicolumn{2}{|c|}{ Wasted } & $4(6.1 \%)$ & $0(0 \%)$ & $4(8.3 \%)$ & \\
\hline \multicolumn{2}{|c|}{ Severely wasted } & $2(3.0 \%)$ & $1(5.6 \%)$ & $1(2.1 \%)$ & \\
\hline
\end{tabular}

Values expressed as mean \pm SD, or counts (\%). p-values are based on Student's t-test or Fisher's exact test. 
Table 2. Correlation between OSA with severity of allergic rhinitis.

\begin{tabular}{lccccc}
\hline Allergic Rhinitis & ALL & \multicolumn{3}{c}{ Obstructive sleep apnea } \\
\cline { 3 - 5 } & & $\begin{array}{c}\text { Positive } \\
\text { (score } \geq 8)\end{array}$ & $\begin{array}{c}\text { Negative } \\
\text { (score }<8)\end{array}$ & p-value & $\begin{array}{c}\text { Odds Ratio (95\% } \\
\text { CI) }\end{array}$ \\
\hline Moderate Persistent & 4 & 3 & 1 & 0.441 & 3.1 \\
Mild Persistent & $(6.1 \%)$ & $(16.7 \%)$ & $(2.1 \%)$ & & $(0.04-250.5)$ \\
Mild Intermittent & 27 & 14 & 13 & $<0.001$ & 9.1 \\
& $(40.9 \%)$ & $(77.8 \%)$ & $(27.1 \%)$ & & $(2.3-44.9)$ \\
& 35 & 1 & 34 & $<0.001$ & 0.02 \\
\hline
\end{tabular}

p-values are based on Fisher's exact test. $\mathbf{9 5 \%} \mathbf{C l}-95 \%$ confidence interval

Among the perceived problems related to sleeping disorders, snoring loudly, heavy breathing, dry mouth on awakening, not listening, and difficulty organizing showed different responses $(p<0.05)$ among the subgroups of allergic rhinitis.

Snoring loudly $(O R=0.06 ; 95 \% \mathrm{Cl}: 0.00-0.51)$, heavy breathing $(\mathrm{OR}=0.11 ; 95 \% \mathrm{Cl}: 0.01-0.60)$, dry mouth on awakening $(\mathrm{OR}=0.72 ; 95 \% \mathrm{Cl}: 0.09$ -0.85 ), not listening (OR $=0.20 ; 95 \% \mathrm{Cl}: 0.05-$ $0.67)$ and difficulty organizing $(O R=0.00 ; 95 \%$ $\mathrm{Cl}: 0.00-0.90)$ were less likely to be observed among patients with mild intermittent allergic rhinitis compared to patients with mild persistent allergic rhinitis.

On the contrary, the odds ratio of snoring loudly (OR 8.93, 95\% Cl: 1.61 - 93.35), not listening (OR $4.07,95 \% \mathrm{Cl}: 1.25-14.30)$, difficulty organizing (OR 19.31, 95\% Cl: 1.02 - 365.55), heavy breathing (OR 14.64, 95\% Cl: $1.05-829.03$ ) and unrefreshed in the morning $(\mathrm{OR} 18.70,95 \% \mathrm{Cl}$ : 1.33 - 1073.00) were more likely among patients with mild persistent allergic rhinitis compared to patients with mild intermittent allergic rhinitis.

\section{DISCUSSION}

This study, using the 22-item SRBD subscale of the $P S Q$ demonstrated an association between the subgroups of allergic rhinitis and SRBD. Patients with mild persistent allergic rhinitis tend to have symptoms related to sleep disordered breathing such as loud snoring, heavy breathing, daytime sleepiness, and inattentiveness compared to patients with mild intermittent allergic rhinitis. This correlation, however, was not observed among patients with moderate persistent allergic rhinitis probably because of the small number of participants enrolled in this category.
The study by Leger, et al. [10] which aimed to assess whether duration and severity of allergic rhinitis were associated with sleep impairment concluded that sleep was significantly more impaired in patients with severe AR than in those with the mild type. However, the duration of allergic rhinitis (intermittent or persistent) had no effect on sleep.

Allergic rhinitis, an lgE-mediated hypersensitivity reaction, is a common allergic disease characterized mainly by nasal congestion and obstruction. This nasal mucosal manifestation results from activation of TH2 lymphocytes, basophils, and mast cells, release of cytokines and chemical mediators, and influx of inflammatory cells, especially eosinophils causing vasodilatation, mucosal edema, increased vascular permeability, and mucus secretion, all of which are characteristic features of allergic inflammation. [1 1]

With an inflamed nasal mucosa and nasal congestion, increased effort is needed to inhale through the nose. This generates a negative pressure during inspiration in the nasal airway leading to nasal collapse and airway obstruction. The increase in nasal resistance and the change in the patency of the nasal airway can have significant effects on breathing manifested as episodes of apnea, hypopnea, arousals, and/or snoring. Total or neartotal nasal obstruction can lead to oral respiration which causes dry mouth upon awakening, a significant observation in this study.

While nasal airway resistance is relatively constant, oral airway resistance varies during waking hours and sleep. During sleep, relaxation and flaccidity of the oral and pharyngeal muscles narrows the airway diameter, resulting in increased oral airway resistance and increased risk of collapse of the upper airway. Since the nose is the preferred route of breathing during sleep, the effect in patients with allergic rhinitis with nasal congestion becomes 


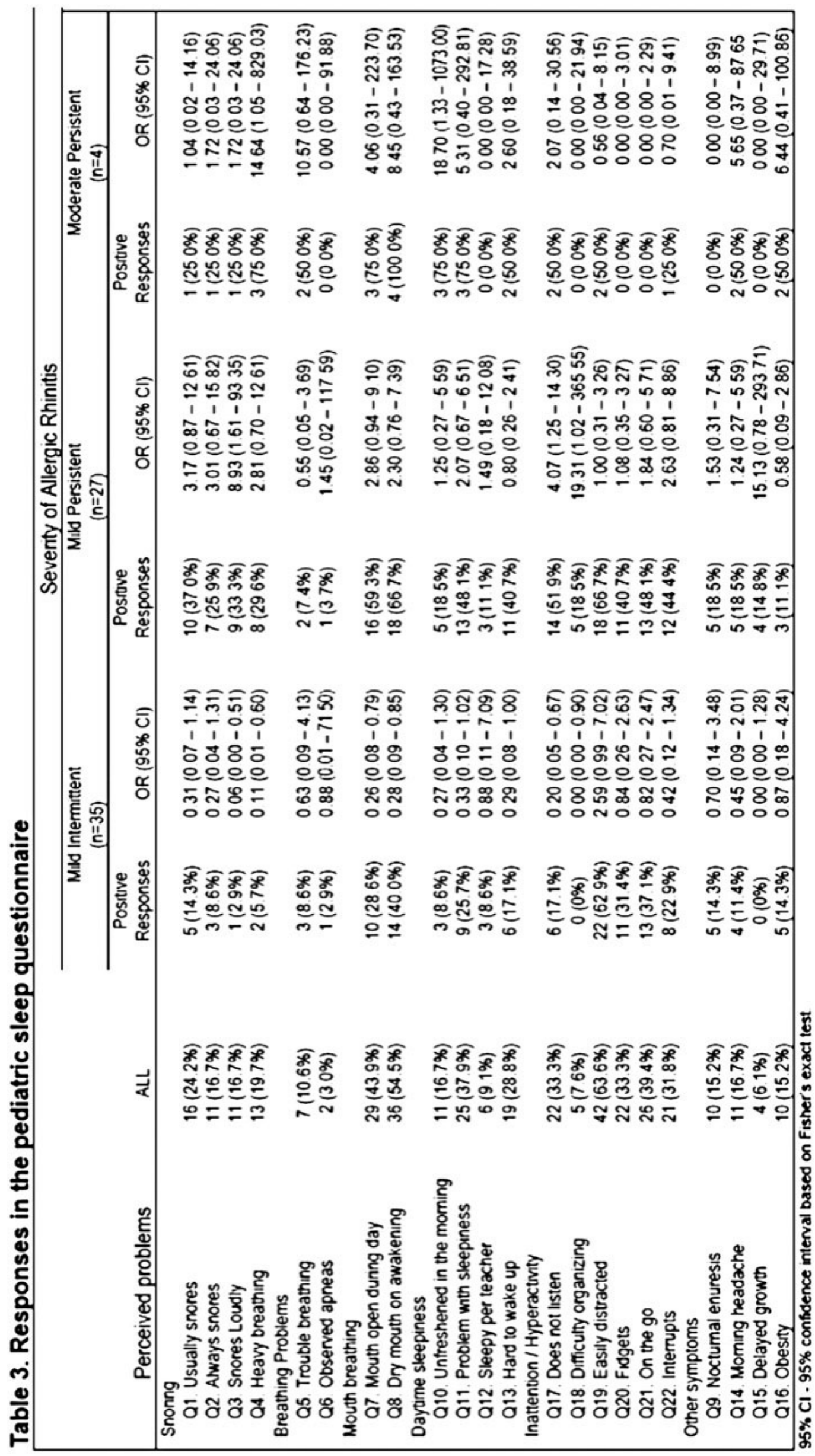


additive, further increasing airway resistance. Thus, the odds of developing OSA or loud snoring in patients with allergic rhinitis becomes higher.[12] This effect was clearly shown in this study, wherein $77.8 \%$ of patients with mild persistent allergic rhinitis compared to $5.6 \%$ of patients with mild intermittent allergic rhinitis had symptoms of OSA.

Houser, et al. [12] used acoustic rhinometry to evaluate nasal patency and nasal congestion in patients with allergic rhinitis with or without OSA. The results showed that the mean congestion factors were significantly higher in allergic rhinitis patients with OSA compared to the non-OSA group showing the correlation between nasal obstruction and presence of sleep-disordered breathing.

Nasal congestion and obstruction can also lead to sleep disruptions or microarousals resulting in sleep fragmentation and unsatisfactory sleep. Sleep loss can cause daytime somnolence and fatigue, mood changes, inattentiveness or compromised alertness, poor school performance, and increased risk of accidents, all of which can adversely affect the quality of life of allergic rhinitis patients.[12,13] Our study showed that $18.5 \%$ of patients with mild persistent allergic rhinitis feel unrefreshed in the morning, which may suggest daytime fatigue.
It was speculated that if nasal congestion can be reduced, symptoms of OSA, sleep quality, and associated symptoms of daytime fatigue may improve. Topical corticosteroid, an anti-inflammatory agent, relieves nasal congestion, thereby increasing nasal patency, decreasing nasal resistance, increasing nasal airflow, and consequently improving sleep quality, and reducing associated daytime fatigue and somnolence. This hypothesis was supported by Craig, et al. wherein the application of topical nasal corticosteroids over an 8-week period significantly reduced nasal stuffiness and improved sleep, daytime fatigue, and quality of life of patients with allergic rhinitis.[13]

\section{CONCLUSION}

There is an association between allergic rhinitis and SRBD using the validated Filipino version of the PSQ. The demographic profile of participants in both the study groups were comparable. OSA has a greater likelihood to be observed among patients with mild persistent allergic rhinitis compared to those with mild intermittent allergic rhinitis. A larger scale research is recommended to strengthen the association of allergic rhinitis and SRBD. 


\section{REFERENCES}

1. Wilmott RW, Bush A, Deterding RR, Boat TF, Chernick V, Ratjen F. Kendig \& Chernick's disorders of the respiratory tract in children. $8^{\text {th }}$ ed. Philadelphia: Elsevier; 2012.

2. Mitchell RB, Garetz S, Moore RH, Rosen CL, Marcus CL, Katz ES, et al. The use of clinical parameters to predict obstructive sleep apnea syndrome severity in children: the childhood adenotonsillectomy (CHAT) study randomized clinical trial. JAMA Otolaryngol Head Neck Surg. 2015;141(2):130-6. Available from: DOI:10.1001/ jamatot.2014.3049.

3. Rosen CL, Wang R, Taylor HG, Marcus CL, Katz ES, Paruthi $S$, et al. Utility of symptoms to predict treatment outcomes in obstructive sleep apnea syndrome. Pediatrics. 2015;135(3):e662-e71. Available from: DOI:10.1542/ peds.2014-3099.

4. Chervin RD, Hedger K, Dillon JE, Pituch KJ. Pediatric sleep questionnaire: validity and reliability of scales for sleepdisordered breathing, snoring, sleepiness, and behavioural problems. Sleep Medicine 1. 2000;21-32. Available from: doi: 10.1016s1389-9457(99)00009-x

5. Chervin RD, Weatherly RA, Garetz SL, Ruzicka DL, Giordani BJ, Hodges EK, et al. Pediatric sleep questionnaire: prediction of sleep apnea and outcomes. Arch Otolaryngol Head Neck Surg. 2007;133(3):216-22. Available from: doi: 10.1001/archotol.133.3.216

6. Maravillosa GB, Go OC, Rivera CRR. Validation study of the Filipino version of the sleep-related breathing disorder subscale within the pediatric sleep questionnaire. University of Michigan Tech Transfer, 2015. Available from: https://secure.nouvant.com/umich/technology/3773/ license/627

7. Perikleous E, Steiropoulos $P$, Nena E, lordanidou M, Tzouvelekis $A$, Chatzmichael $A$, et al. Association of asthma and allergic rhinitis with sleep-disordered breathing in childhood. Front Pediatr. 2018;6:250. Available from: doi:10.3389/fped.2018.00250.

8. Chirakalwasan N, Ruxrungtham K. The linkage of allergic rhinitis and obstructive sleep apnea. Asian Pac J Allergy Immunol. 2014;32:276-86. Available from: http://apjaijournal.org/wp-content/uploads/2016/10/2ThelinkageA PJAIVol32No4December2014P276.pdf

9. Brozek JL, Bousquet J, Bonini S, Canonica GW, Casale TB, van Wijk RG, et al. Allergic rhinitis and its impact on Asthma
Guidelines. 2010. Available from: https://www.euforea. eu/sites/default/files/2018-08/2010-ARIA-Report.pdf

10. Leger D, Maesano IA, Carat F, Rugina M, Chanal I, Pribil $C$, et al. Allergic rhinitis and its consequences on quality of sleep: an unexplored area. Arch Intern Med. 2006;166:1744-8. Available from: doi: 10.1001/ archinte.166.16.1744

11. Sin B, Togias A. Pathophysiology of allergic and non-allergic rhinitis. Proc Am Thorac Soc. $2011 ; 8(1): 106-14$. Available from: doi: 10.1513/pats.201008-057RN

12. Houser SM, Mamikoglu B, Aquino BF, Moinuddin R, Corey JP. Acoustic rhinometry findings in patients with mild obstructive sleep apnea. Otolaryngol Head Neck Surg. 2002;126:475-80. Available from: doi: 10.1067/ mhn.2002.124848

13. Craig TJ, Teets S, Lehman EB, Chinchilli VM, Zwillich C. Nasal congestion secondary to allergic rhinitis as a cause of sleep disturbance and daytime fatigue and the response to topical nasal corticosteroids. J Allergy Clin Immunol. 1998;101(5):633-7. Available from: doi:10.1016/ s0091-6749(98)70171-x

cc)(1) Open Access This article is licensed under a cc. Creative Commons Attribution-NonCommercialShareAlike 4.0 International License, which permits use, share - copy and redistribute the material in any medium or format, adapt - remix, transform, and build upon the material, as long as you give appropriate credit, provide a link to the license, and indicate if changes were made. You may do so in any reasonable manner, but not in any way that suggests the licensor endorses you or your use. You may not use the material for commercial purposes. If you remix, transform, or build upon the material, you must distribute your contributions under the same license as the original. You may not apply legal terms or technological measures that legally restrict others from doing anything the license permits. The images or other third party material in this article are included in the article's Creative Commons license, unless indicated otherwise in a credit line to the material. If material is not included in the article's Creative Commons license and your intended use is not permitted by statutory regulation or exceeds the permitted use, you will need to obtain permission directly from the copyright holder. To view a copy of this license, visit https://creativecommons.org/licenses/by-nc-sa/4.0/. 


\section{APPENDIX A}

Filipino Version of the Sleep-Disordered Breathing Subscale Within the Pediatric Sleep Questionnaire

PALATANUNGAN UKOL SA PAGTULOG NG MGA BATA: SUBSCALE SA KARAMDAMAN SA PAGHINGA HABANG NATUTULOG

(Fiipino version of the Sleep-disordered oreathing suoscale within the pedatix sleep questionnaire)

Pangalan ing oata

Pangalan ng sumasagot sa palatanungan:

$1 D=$

Petsa:

Paklsagutan ang mga tanong ukol sa klos/gawl ng bata sa pagtulog at sa pagkaglsing. Ang mga tanong $n$ a Ito ay tumutukoy 83 karaniwang Ikinikilos $\mathrm{ng}$ Data 8 a nakaraang Duwan, at hindi lamang ng mga nakaraang araw dahil ang mga kllos na ito ay maaring hind pangkarantwan lalo na kung ang bata ay may karamdaman. Bliugan ang tamang kasagutan o lsulat ng mallnaw sa patiang na nararapat $\mathrm{Ang}$ "O" ay nangangahulugang "OO". ang " $\mathrm{H}$ " ay nangagahulugang "hind" at ang "HA" ay nangangahulugang "hindl alam/angkop."

HABANG NATUTULOG. ANG BATA BA AY:

num inilk nang higt sa kalanatl ng oras ng pagtuog?

parating numinilk?

numinilk nang malakas?

may madiga:" or malakas na pagninga?

may nirap s3 pagninga o nagpupumlit makahinga?

O H HA

O H HA

O H HA

NAKITA MO BA ANG BATA NA HUMINTO SA PAGHINGA SA GABI?

ANG BATA BA AY:

madalas huminga sa pamamagtan ng bolg sa umaga

natutuyo ang bidig sa paggising sa umaga?

paminsan-minsang nainl sa kama?

O H HA

O H HA

O H HA

ANG BATA BA AY:

pagod ang pakiramoam pagkagising sa umaga?

Inaantok sa umaga?

O H HA

O H HA

MAY GURO O TAGAPANGALAGA BA ANG NAKAPAGSABI

NA ANG BATA AY PARANG INAANTOK MAGHAPON?

O H HA

MAHIRAP BANG GISINGIN ANG BATA SA UMAGA?

$\mathrm{OH} \mathrm{HA}$

MAS AKIT BA ANG ULO NG BATA PAG GUMIGISING SA UMAGA?

O H HA

HUMINTO BA SA PAGLAKI SA NORMAL NA BILIS SA ANUMANG ORAS MULA SA PAGKASILANG NG BATA?

$\mathrm{OH}$ HA

ANG TIMBANG BANG BATA AY HIGIT SA NORMAL?

O H HA

ANG BATA NA TTO AY MADALAS NA:

parang hind naklkinig kanlt slya mismo ang vnakausap mo

nahinirapan mag-organisa ng mga gawain

macaling matawag ang pansin (o magambaia ang atensyon)

ng mga raguinan o ingay na nagmumula sa laoas

nindl mapakall ang kamay o paa o di mapakall sa upuan

parating gumagalaw o parang "sinuslang motor

sumasaba: sa usapan o nangugulo 63 loa ( 53 mga usapan

o sa laro

O H HA

O H HA

O H HA

H HA
0 H HA

O H HA 